\title{
How to use the WHO criteria to focus a hand hygiene campaign
}

\author{
A Jeurissen*, S Monsecour, V Cossey, A Schuermans \\ From International Conference on Prevention \& Infection Control (ICPIC 2011) \\ Geneva, Switzerland. 29 June - 2 July 2011
}

\section{Introduction / objectives}

Proper hand hygiene is critical to prevent healthcare associated infections. Therefore, measurement of hand hygiene compliance is an important tool in infection prevention. After multi model hand hygiene campaign (HHC) compliance is known to remain low.

\section{Methods}

Between October and December 2010, after an intensive $\mathrm{HHC}$ of ten years in our 1894-bedded tertiary care centre, hand hygiene opportunities ( $\mathrm{HHO}$ ) as defined according to the 5 categories from the WHO were measured by direct observation. Compliance rates (CR) were calculated as the number of hand hygiene activities (HHA) divided by the HHO.

\section{Results}

A total of $1007 \mathrm{HHO}$ were documented: 134 in the protective isolation ward, 113 in the medical ward, 566 in the intensive care unit (ICU), and 161 in the surgical ward, resulting in CRs of $49 \%$ (66/134), 51\% (58/113), $28 \%(159 / 566)$, and $51 \%(82 / 161)$, respectively. The CR in the ICU was statistically lower $(\mathrm{p}<0.001)$ compared to the other wards and this was due to the absence of hand hygiene after glove use. In all wards except the protective isolation ward, CRs were statistically lower ( $p$ $<0.001$ ) before patient contact (WHO indications 1 and 2) than after patient contact (WHO indications 3, 4 and 5).

\section{Conclusion}

Most increase in compliance can be achieved by focusing our new $\mathrm{HHC}$ on performing hand hygiene before aseptic tasks.

Hospital hygiene and infection control, Uz Gasthuiberg, Leuven, Belgium Full list of author information is available at the end of the article

\section{Disclosure of interest}

None declared.

Published: 29 June 2011

doi:10.1186/1753-6561-5-S6-P253

Cite this article as: Jeurissen et al:: How to use the WHO criteria to focus a hand hygiene campaign. BMC Proceedings 2011 5(Suppl 6):P253.
Submit your next manuscript to BioMed Central and take full advantage of:

- Convenient online submission

- Thorough peer review

- No space constraints or color figure charges

- Immediate publication on acceptance

- Inclusion in PubMed, CAS, Scopus and Google Scholar

- Research which is freely available for redistribution
() Bïmed Central
() Biomed Central

(C) 2011 Jeurissen et al; licensee BioMed Central Ltd. This is an open access article distributed under the terms of the Creative Commons Attribution License (http://creativecommons.org/licenses/by/2.0), which permits unrestricted use, distribution, and reproduction in any medium, provided the original work is properly cited. 